\title{
Adenovirus and Rotavirus Associated Diarrhoea in under 5 Children from Enugu Rural Communities, South East Nigeria
}

\author{
Beckie Nnenna Tagbo ${ }^{1,2}$, Chinedu Michael Chukwubike $\left.{ }^{3 *}{ }^{(}\right)$, Roseline Ifeyinwa Ezeugwu ${ }^{4}$, \\ Ebele Oliaku Ani ${ }^{3}$ \\ ${ }^{1}$ Institute of Child Health, University of Nigeria Teaching Hospital, Ituku-Ozalla, Nigeria \\ ${ }^{2}$ Department of Paediatrics, University of Nigeria Teaching Hospital, Ituku-Ozalla, Nigeria \\ ${ }^{3}$ Department of Microbiology, University of Nigeria Teaching Hospital, Ituku-Ozalla, Nigeria \\ ${ }^{4}$ Department of Applied Microbiology and Brewing, Enugu State University of Science and Technology, Enugu, Nigeria \\ Email: *chinedumbc@yahoo.com
}

How to cite this paper: Tagbo, B.N., Chukwubike, C.M., Ezeugwu, R.I. and Ani, E.O. (2019) Adenovirus and Rotavirus Associated Diarrhoea in under 5 Children from Enugu Rural Communities, South East Nigeria. World Journal of Vaccines, 9 , 71-83.

https://doi.org/10.4236/wjv.2019.93005

Received: May 30, 2019

Accepted: August 13, 2019

Published: August 16, 2019

Copyright $\odot 2019$ by author(s) and Scientific Research Publishing Inc. This work is licensed under the Creative Commons Attribution International License (CC BY 4.0).

http://creativecommons.org/licenses/by/4.0/

\begin{abstract}
Globally, diarrhoea is the second commonest infectious cause of death in children less than 5 years old. It is estimated that more than one billion diarrhoea episodes occur every year causing up to 700,000 deaths among children younger than 5 years of age. Seventy-two percent of these deaths occur in children below two years and enteric viruses have been recognized as a major cause of childhood diarrhoea. This study was undertaken to determine the prevalence of enteric Adenoviruses and Rotaviruses in children with diarrhoea in rural Enugu communities of Enugu State South East Nigeria. Methods: Stool samples were collected from children less than 5 years with diarrhoea seen in any of the participating hospitals in Enugu State. Samples were collected between June 2015 and May 2017. Detection of rotavirus and enteric adenovirus antigens were performed using commercially available ELISA kit (Oxoid-Prospec $\mathrm{T}^{\circledast}$ ). Demographic data of the children were also collected. Results: Of the 290 stool samples that had sufficient materials for adenovirus and rotavirus ELISA, $14(4.8 \%)$ and $89(30.7 \%)$ were positive for enteric adenovirus and rotavirus respectively. $3(1 \%)$ were co-infected with adenovirus and rotavirus. Rotavirus positive cases were more among hospitalized patients while enteric adenovirus was more among outpatients. Marked peaks of rotavirus positivity were seen in January of each year but no peak was seen among adenovirus positive cases. Higher vomiting frequencies and severe dehydration were more among rotavirus positive cases compared to adenovirus positive cases ( $\mathrm{p}=0.030$ and 0.001 respectively). Conclusion: Many diarrhoea cases among children aged $<5$ in the population studied were associated with enteric adenoviruses and rotavirus. This finding suggests that en-
\end{abstract}


teric viral agents (adenovirus and rotavirus) are important aetiologies for childhood diarrhoea in Enugu state Nigeria. Appropriate preventive, diagnostic and treatment interventions should be instituted so as to reduce the mortality and morbidity associated with these viruses.

\section{Keywords}

Adenovirus, Rotavirus, Diarrhoea, Children, Enugu Nigeria

\section{Introduction}

Globally, diarrhoea is the second commonest infectious cause of death in children less than five years old [1]. It is estimated that more than one billion diarrhoea episodes occur every year causing up to 700,000 deaths among children younger than 5 years of age [2]. Seventy-two percent of these deaths occur in children below two years and enteric viruses have been recognized as a major cause of childhood diarrhoea [3] [4].

Gastroenteritis caused by viral agents is gradually increasing particularly in the developed countries [5]. Although the improvement in sanitation has significantly decreased the incidence of gastroenteritis caused by bacteria and parasites, it had little effect on viral gastroenteritis [5] [6].

The viral causes of gastroenteritis in humans include rotaviruses, enteric adenoviruses, caliciviruses (norovirus and sapovirus) and astroviruses. Although some other viruses associated with gastroenteritis in humans have been reported, their etiological roles have not yet been established [5].

Rotavirus is a double segmented RNA virus that belongs to the Reoviridae family. Rotavirus gastroenteritis is a major public health concern globally, estimated to cause 215,000 (range, 197,000 - 233,000) deaths among children $<5$ years of age in 2013. Four countries (India, Nigeria, Pakistan, and Democratic Republic of Congo) accounted for approximately half (49\%) of all estimated rotavirus deaths in 2013 [7]. In Africa, Nigeria has one of the highest under 5 rotavirus disease prevalence of $56 \%$ [6] and mortality due to rotavirus accounted for an estimated 31,000 deaths in 2013 [8]. Rotavirus is transmitted via the feco-oral route and, rotavirus gastroenteritis is more frequently observed during the winter months [6]. Generally, its clinical course is considered to be more severe compared to the course of other viral gastroenteritis. It begins with a sudden onset of mild fever; vomiting and loose stools; blood and mucus in stool are not seen at all. Vomiting may last for 2 - 3 days and diarrhoea lasts for average of 4 5 days [5] [6].

Adenoviruses belong to the Adenoviridae family and genus Mastadenovirus. They are non-enveloped icosahedral viruses with a linear, double-stranded DNA genome that can cause a wide spectrum of clinical diseases, including acute respiratory illness, epidemic keratoconjunctivitis, acute haemorrhagic cys- 
titis, hepatitis, myocarditis and gastroenteritis [9] [10].

Adenoviruses can cause epidemics and sporadic infections in all geographical regions of the world. The adenovirus type 40 and 41 cause gastroenteritis. The gastroenteritis caused by these types is mostly seen in children less than 2 years old.

They can be seen throughout the year with no seasonal variation [9] [11]. Definite diagnoses of gastroenteritis caused by these viruses are important; as it will decrease the unnecessary use of antibiotics, especially in clinics with large patient population.

In Africa where there is a high burden of diarrhoea it is important to accurately document organisms and institute appropriate control and prevention measures.

This study was undertaken to determine the prevalence and clinical significance of enteric Adenoviruses and Rotaviruses in children with gastroenteritis in rural Enugu communities of Enugu State South East Nigeria.

\section{Materials and Methods}

\subsection{Study Population}

This study was conducted between June 2015 and May 2017 among children less than 5 years old with diarrhoea who presented in any of the participating hospitals located within rural communities of the three senatorial zones of Enugu State. In Enugu State, there are two markedly different seasons: the rainy season, which extends from April to October, and the dry season, which extends from November to the end of March. The coolest months are November, December, and January, when the minimum temperature may reach $7^{\circ} \mathrm{C}$ in the Northern Senatorial Zone (Nsukka). During the warm part of the year, March and April, the maximum temperature may reach $35^{\circ} \mathrm{C}$. In the remaining months of the year, the daily ambient temperature fluctuates between $12^{\circ} \mathrm{C}$ and $25^{\circ} \mathrm{C}$. Majority of the population in these rural communities are peasant farmers. Animal husbandry is also common [12].

\subsection{Methods}

\subsubsection{Study Sites}

The hospitals where samples were collected were: Nenwe Health Centre (Baby Way), Nenwe Aninri L.G.A, Owelle Court Health Centre, Awgu L.G.A, Cottage Hospital Amorji Nike, Enugu East L.G.A and Nsukka Health Centre, Nsukka L.G.A. These hospitals serve as the first point of care for many rural dwellers and surrounding communities as catchment area.

\subsubsection{Data Collection}

Stool samples were collected from under five children who had diarrhoea with or without vomiting admitted or attended to from June 2015 to May 2017.

Diarrhoeic children included in the study were hospitalised in the diarrhoea wards or seen as out-patients, with acute or chronic/persistent diarrhoea. Diar- 
rhoea was defined as three or more watery stools within 24 hours. An episode of acute diarrhoea was defined as diarrhoea with duration between 24 hours and less than 14 days. Chronic/Persistent diarrhoea was defined as diarrhoea lasting for 14 days or more. Demographic and clinical information were collected using a questionnaire, after informed consent had been obtained from mothers or care givers of children.

\subsubsection{Stool Sampling}

Stool specimens were obtained mostly within 48 hours of admission to exclude nosocomial infections and before leaving the clinic for out-patients. The stool samples were collected in clean and well labelled screw-capped containers and delivered to the facility laboratory within one hour. The samples were stored temporarily at $+4^{\circ} \mathrm{C}$ to $+8^{\circ} \mathrm{C}$ before transporting under ice to Virology Laboratory of University of Nigeria Teaching Hospital Ituku-Ozalla, Enugu. In the Laboratory the samples were stored at $-80^{\circ} \mathrm{C}$ till use. The study protocol was approved by the Health Research Ethics Committee of the University of Nigeria Teaching Hospital, Ituku-Ozalla, Enugu. The participants were informed using simple local language about the infection, aim of the research and the benefits of the study after which oral consent was obtained from the mothers and care-givers of the children.

All demographic and clinical data collected were entered and analyzed using SPSS Version 20.0 software. Differences in proportions of adenovirus and rotavirus positivity in relation to the various parameters were tested using the chi-square $\left(\chi^{2}\right)$ test and Fisher's Exact test as appropriate. The results were presented using descriptive statistics in tables and chart. Significance was set at $\mathrm{p}<0.05$.

\subsection{Adenovirus and Rotavirus Antigen Detection}

Adenovirus and Rotavirus antigens were detected using the commercially available ELISA Kits, ProSpecT ${ }^{\circledast}$ (Oxoid LTD Wade Road, Hants, RG24 8PW, UK). Adenovirus kit was designed to detect Human adenovirus (HAdV) types 40 and 41 and ProSpecT $\mathrm{T}^{\oplus}$ Rotavirus kit designed to detect Group A Rotavirus from 10\% faecal suspensions according to the manufacturer's instructions. The optical density value of samples greater or equal to the mean absorbance of the negative control +0.100 was considered positive for adenovirus while values greater than or equal to the mean absorbance of negative control +0.200 was considered positive for Group A rotaviruses.

\section{Results}

A total of 325 stool samples were collected but only 290 were adequate for detection of adenovirus and rotavirus by ELISA. Of the 290 diarrhoeal children whose stool samples were enough for ELISA, 14 (4.8\%; 14/290) and 89 (30.7\%; 89/290) were positive for enteric adenoviruses and Group A rotavirus respectively (Table 1). Among those that were positive for rotavirus, the virus was more common among those hospitalized than those seen as out-patients $(75.3 \%$ vs $24.7 \%, \mathrm{p}=$ 
0.328). Those that were seen as out-patients were more infected with adenovirus than those hospitalized ( $78.6 \%$ vs $21.4 \%, \mathrm{p}=0.542)$.

There was no significant difference between gender and rotavirus $(\mathrm{p}=0.747)$ and adenovirus $(\mathrm{p}=0.973)$, although rates of rotavirus and adenovirus were higher in males (56.2\% and $57.1 \%$ respectively) (Table 1). Co-infection (both adenovirus and rotavirus) was seen in $1 \%$ (3/290) of cases (2 Males and $1 \mathrm{Fe}$ male) (Table 2). From Table 1, the highest prevalence of both rotavirus and adenovirus was in the 6 - 11 months group (51.7\% and $71.4 \%$ respectively). There was no significant relationship between age groups and type of viral diarrhoea $(\mathrm{p}=0.741$ and $\mathrm{p}=0.527)$. There was a strong significant relationship $(\mathrm{p}=$ 0.001 and $p=0.044$ ) between the type of diarrhoea (acute or chronic/persistent diarrhoea) and the viral diarrhoea pathogen. Higher frequency of diarrhoea episodes ( $>6$ times within 24 hours period) was more $(42.7 \%)$ among rotavirus gastroenteritis group than non-rotavirus gastroenteritis $(33.2 \%)(\mathrm{p}=0.088)$. Similar finding was obtained among those that were enteric adenoviruses positive and negative respectively $(42.9 \%$ vs $35.9 \%$; $=0.795)$. Higher vomiting frequencies (more than 3 times within 24 hours) were seen more among rotavirus and adenovirus positive cases than the negative cases. However, the differences were not statistically significant ( $\mathrm{p}=0.269$ and 0.091 respectively). Longer duration (in days) of vomiting was more common in rotavirus positive than rotavirus negative cases $(31.5 \%$ vs $16.4 \%$; $=0.038)$. This was not seen among children with or without adenoviruses $(\mathrm{p}=0.082)$.

Table 1. Demographic and clinical characters of the subjects with and without adenovirus and rotavirus associated diarrhea in rural Enugu communities Enugu State.

\begin{tabular}{|c|c|c|c|c|c|c|}
\hline $\begin{array}{c}\text { Demographic and } \\
\text { Clinical Characteristics }\end{array}$ & $\begin{array}{l}\text { RV Positive } \\
\text { No (\%) }\end{array}$ & $\begin{array}{l}\text { RV Negative } \\
\text { No (\%) }\end{array}$ & P-value & $\begin{array}{l}\text { AdV Positive } \\
\text { No (\%) }\end{array}$ & $\begin{array}{l}\text { AdV Negative } \\
\text { No (\%) }\end{array}$ & p-Value \\
\hline Total $(\mathrm{n}=290)$ & $89(30.7)$ & $201(41.8)$ & & $14(4.8)$ & $276(95.2)$ & \\
\hline \multicolumn{7}{|l|}{ Treatment } \\
\hline Hospital Admission $(\mathrm{n}=207)$ & $67(75.3)$ & $140(69.7)$ & 0.328 & $3(21.4)$ & $80(29.0)$ & 0.542 \\
\hline Out Patient $(\mathrm{n}=83)$ & $22(24.7)$ & $61(30.3)$ & & $11(78.6)$ & $196(71.0)$ & \\
\hline \multicolumn{7}{|l|}{ Gender } \\
\hline Female $(n=123)$ & $39(43.8)$ & $84(41.8)$ & 0.747 & $6(42.9)$ & $117(42.4)$ & 0.973 \\
\hline Male $(\mathrm{n}=167)$ & $50(56.2)$ & $117(58.2)$ & & $8(57.1)$ & $159(57.6)$ & \\
\hline \multicolumn{7}{|l|}{ Age Group (Months) } \\
\hline $0-5(\mathrm{n}=50)$ & $11(12.4)$ & $39(19.4)$ & & $1(7.1)$ & $49(17.8)$ & \\
\hline $6-11(n=138)$ & $46(51.7)$ & $92(45.8)$ & & $10(71.4)$ & $128(46.4)$ & \\
\hline $12-17(n=63)$ & $20(22.5)$ & $43(21.4)$ & 0.741 & $2(14.3)$ & $61(22.1)$ & 0.527 \\
\hline $18-23(n=17)$ & $6(6.7)$ & $11(5.5)$ & & $1(7.1)$ & $16(5.8)$ & \\
\hline $24-29(\mathrm{n}=13)$ & $4(4.5)$ & $9(4.5)$ & & $0(0)$ & $13(4.7)$ & \\
\hline $30-59(n=9)$ & $2(2.2)$ & $7(3.5)$ & & $0(0)$ & $9(3.3)$ & \\
\hline
\end{tabular}




\section{Continued}

Type of Diarrhoea

$$
\text { Acute }(\mathrm{n}=194)
$$

88 (98.1)

$86(42.8)$

0.001

$12(85.7)$

$162(58.7)$

0.044

Acute/Persistent $(\mathrm{n}=116)$

$1(1.1)$

$115(57.2)$

$2(14.3)$

$114(41.3)$

\section{Maximum Number of Diarrhoea Episodes in 24 Hours}

$$
\begin{aligned}
& 1-3 \text { Times }(\mathrm{n}=87) \\
& 4-5 \text { Times }(\mathrm{n}=97) \\
& \geq 6 \text { Times }(\mathrm{n}=105) \\
& \text { Missing Data }(\mathrm{n}=1)
\end{aligned}
$$$$
18(20.2) \quad 69(34.3)
$$

$33(37.1)$

$64(31.8)$

0.088

5 (35.7)

$82(29.7)$

$38(42.7)$

67 (33.3)

$0(0)$

$1(0.5)$

$3(21.4)$

$94(34.1)$

0.795

$6(42.9)$

$99(35.9)$

$0(0)$

$1(0.4)$

Duration of Diarrhoea (Days)

$$
\begin{gathered}
1-4 \text { Days }(n=177) \\
5 \text { Days }(n=45) \\
\geq 6 \text { Days }(n=67) \\
\text { Missing Data }(n=1)
\end{gathered}
$$

\section{Maximum Number of Vomiting in 24 Hours}

$$
\begin{gathered}
\text { No Vomiting }(\mathrm{n}=84) \\
1 \text { Time }(\mathrm{n}=15) \\
2 \text { Times }(\mathrm{n}=18) \\
\geq 3 \text { Times }(\mathrm{n}=173)
\end{gathered}
$$

\section{Duration of Vomiting (Days)}

$$
\begin{gathered}
\text { No Vomiting }(\mathrm{n}=84) \\
1 \text { Day }(\mathrm{n}=25) \\
2-4 \text { Days }(\mathrm{n}=120) \\
\geq 5 \text { Days }(\mathrm{n}=61)
\end{gathered}
$$

Temperature ( $\left({ }^{\circ} \mathrm{C}\right.$ on Presentation)

$$
\begin{gathered}
\text { Normal }(\mathrm{n}=36) \\
\text { Mild Fever }(\mathrm{n}=153) \\
\text { Severe Fever }(\mathrm{n}=32) \\
\text { High Fever }(\mathrm{n}=53) \\
\text { Missing Data }(\mathrm{n}=16)
\end{gathered}
$$

\section{Dehydration}

$$
\begin{gathered}
\text { None }(\mathrm{n}=44) \\
\text { Mild }(\mathrm{n}=72) \\
\text { Moderate }(\mathrm{n}=28) \\
\text { Severe }(\mathrm{n}=140) \\
\text { Missing Data }(\mathrm{n}=6)
\end{gathered}
$$$$
52(58.4)
$$$$
125(62.2)
$$$$
16(18.0)
$$$$
29(14.4)
$$$$
21(23.6)
$$$$
46(22.9)
$$$$
0(0)
$$$$
22(24.7)
$$$$
62(30.8)
$$$$
2(2.2)
$$$$
13 \text { (6.5) }
$$

$12(6.0)$

$59(66.3)$

$114(56.7)$

$\begin{array}{cc}22(24.7) & 62(30.8) \\ 7(7.9) & 18(9.0) \\ 32(36.0) & 88(43.8) \\ 28(31.5) & 33(16.4)\end{array}$

8 (57.1)

0.001 
Table 2. Enteric adenovirus and rotavirus co-infections among U5 children with diarrhoea in rural Enugu communities, Enugu State South East Nigeria.

\begin{tabular}{cccc}
\hline Gender & $\begin{array}{c}\text { Co-Infection } \\
\text { (Adv and Rv Positive) Present }\end{array}$ & $\begin{array}{c}\text { Co-Infection } \\
\text { (Adv and Rv Negative) Absent }\end{array}$ & Total \\
\hline Male & 2 & 165 & 167 \\
Female & 1 & 122 & 123 \\
Total & $3(1)$ & $287(99)$ & $290(100)$ \\
\hline
\end{tabular}

Cases of severe dehydration were more in children with rotavirus diarrhoea than those without rotavirus $(75.3 \%$ vs $36.3 \%$; $p=0.001)$. Similar pattern was not observed among those that were adenovirus positive and negative $(\mathrm{p}=$ $0.324)$. In terms of seasonality, $95 \%$ of all confirmed cases of rotavirus gastroenteritis during the study period occurred in December, January, February and March. Enteric adenoviruses were detected almost round the year in this study with no particular seasonal variation (Figure 1).

\section{Discussion}

This study on Rotavirus and Adenovirus acute gastroenteritis (AGE) was conducted among U5 children from rural communities in Enugu State. Results showed that rotavirus was more commonly associated with diarrhea (30.7\%) in infants and young children less than five years old. This finding is consistent with that conducted in Nigeria, neighboring Niger Republic, Burkina Faso, and in Tanzania and Nepal where prevalence rates of $30.8 \%, 30.6 \%, 30.8 \%, 32.5 \%$ and $31.6 \%$ were reported respectively [13] [14] [15] [16]. This proportion was however lower than earlier reports of $56 \%$ and $46 \%$ in Enugu Nigeria [6] [17]. The differences in prevalence may be epidemiological or methodological because it is believed that studies with high prevalence were hospital based, whereas community-based studies give lower prevalence [18]. It could also be explained by the season of the year studies were carried out and the viral detection methods used.

On the other hand, there was no previous data on adenovirus AGE in South-Eastern Nigeria and our study aimed to fill this gap. Adenovirus was responsible for $4.8 \%$ of diarrhoea among the population studied. Studies in North-Western Nigeria and South-Western Nigeria reported 23\%, $12.4 \%$ and 18\% respectively [19] [20] [21]. The possible reason for the low detection of enteric adenoviruses in this study when compared with other studies done earlier in Nigeria could be the fact that this study recruited both hospitalized patients and out-patients while earlier studies in Nigeria considered only hospitalized children. However similar prevalence was reported in Tanzania (3.5\%) [9] and Iran (3.3\%) [22]. The great majority of diarrhoea with adenoviruses in our setting is probably undiagnosed and under-reported as it is not routinely tested for. Adenovirus Serotypes 40 and 41 have been isolated from Under five years' children with diarrhoea and, in a number of cases, are second only to rotavirus infection [20]. 


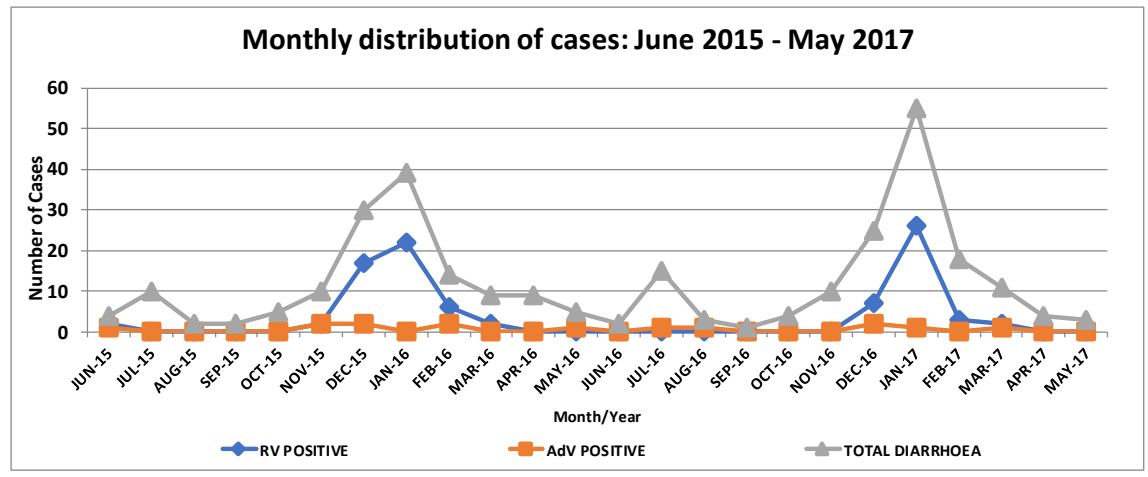

Figure 1. Seasonal pattern of enteric adenovirus and rotavirus among U5 children in rural communities of Enugu State, South East Nigeria.

Mixed rotavirus and adenovirus infection were responsible for $1 \%$ of the diarrhea among the subjects in this study. Similar prevalence (1.56\% and $1.95 \%)$ was reported in Baghdad [23] and Congo [24] respectively. The rotavirus-adenovirus co-infection rates seen in this study was lower than 5.4\% in Edo state Nigeria [25], 4.4\% in Iran [26] and Turkey [5]. Almost all cases of rotavirus and adenovirus associated diarrhoea in this study were less than 2 years of age with a peak age in the 6 to 11 months old. This finding agrees with several reports in African countries [19] [24] and Iraq [27]. This may be partly due to the fact that in developing settings like ours, the early peak of rotavirus diarrhea in life may result from early exposure to contaminated sources, undetectable antibodies in early infancy as well as overcrowding [6]. The occurrence of rotavirus infection in these younger children underscores the need for the introduction of rotavirus vaccination in early infancy before exposure to the first symptomatic natural infection, which is usually the most severe [28]. There is a sharp decline from 12 months when most children would have been exposed a few times and would have acquired natural immunity against the viruses [28] [29]. This study also showed higher numbers of viral infection in males than in females, as seen by other researchers [6] [19] [27] [30] [31]. The reasons for observed higher prevalence among male gender is not quite clear [17]. Other studies have found that girls were more susceptible to rotavirus and adenoviruses gastroenteritis than boys [20] [32] [33], but these differences were however not significant ( $p>0.05)$. Whether this difference is due to sex vulnerability or by chance needs further investigation. But in the study area, the belief that male children would take over from their parents encourages caregivers to seek care more for their male children.

During the two-year study, there was a significant seasonal peak of rotavirus gastroenteritis between December and March. In Enugu Nigeria these months correspond to the dry, cold season of the year when the prevalence of rotavirus was observed to be high. However, this rotavirus positivity dropped in the other months of the year to about $1 \%$. Other studies have identified peaks of rotavirus gastroenteritis during the same period of the year in other tropical countries [17] 
[34] [35]. We did not observe similar marked seasonal distribution of infection among adenovirus positive cases. This pattern has been reported by some authors in Nigeria [19] [20] [21] [22] and Iran [22]. However other authors reported a marked seasonality for enteric adenovirus in Botswana [36] in Iran [26], in India [37]. The low number of adenovirus positive cases in this study could affect the display of seasonality. So, the number of cases was too small to draw any significant conclusion about the seasonality of adenovirus infection. Study of longer duration is therefore advocated.

Adenovirus diarrhoea was more common among out-patients than inpatients and this could have resulted from the fact that many of the infections due to adenovirus were mild and were not likely to be associated with severe dehydrating diarrhoea that required hospitalization. Besides, longer duration of vomiting and dehydration which is a prominent feature of rotavirus diarrhoea was observed in this study. More children with rotavirus diarrhoea had severe dehydration and longer duration of vomiting than those who were rotavirus negative. Therefore, severe dehydration was more among rotavirus positive cases than adenovirus positive cases. This pattern of finding has been reported earlier [17] [19] [35].

Effective rotavirus vaccination could reduce the overall burden of the disease. To date, rotavirus vaccines have not been introduced into the routine immunization schedule in Nigeria. Although it is available in the private market, it is expensive and outside the reach of many. None of our subjects had received rotavirus vaccine.

Currently, four World Health Organization (WHO) pre-qualified rotavirus vaccines are commercially available and have been introduced into many countries worldwide [38]. Rotarix (GSK Biologicals, Belgium) is a monovalent, attenuated human rotavirus strain that has shown good vaccine efficacy and safety in Latin America, Europe and Africa. RotaTeq (Merck \& Co. Whitehouse, PA) is a pentavalent, bovine human rotavirus reassortant vaccine that has demonstrated good vaccine efficacy and safety in the United States, Europe and Africa. Rotavac (Monovalent naturally attenuated vaccine) (Bharat Biotech International, India) was licensed for use in India and in January 2018 was pre-qualified for the Global Alliance for Vaccines and Immunization (GAVI) market [38]. Efficacy data are available from three sites in India. The newest vaccine, Rotasill is a pentavalent vaccine (Serum Institute of India) pre-qualified for global use in September 2018. Efficacy data are available from two countries- India and Niger Republic (Africa). Efficacy of these vaccines has ranged from $80 \%$ to $98 \%$ in industrialized countries, including Latin America, and 39\% to 77\% in developing countries, such as Africa and Asia [38]. WHO recommends the inclusion of rotavirus vaccines in all national routine immunization schedules [29]. We did not record any death among the study subject(s) during the study period.

\section{Limitations}

This study targeted only those who presented to the hospital and a good number 
of children may not have had access to hospital care. Besides we did not consider other possible enteric pathogens or the use of molecular methods for the detection of the diarrhoeal etiologic agents.

\section{Conclusion}

Our study reported for the first time the burden of adenovirus and rotavirus gastroenteritis among children aged $<5$ in rural Enugu communities South East Nigeria. Enteric adenoviruses and rotavirus were shown to be associated with $4.8 \%$ and $30.7 \%$ of diarrhoea cases among the subjects respectively. Although no death was reported, the infections still pose a serious threat to child survival. More detailed studies with longer duration are necessary in order to determine the viral strains and other epidemiological and clinical features of childhood diarrhoea caused by these viruses.

\section{Acknowledgements}

We thank the health care workers (the doctors, the officers in-charge, nurses, community health workers and record officers) in the various hospitals where samples were collected. We also appreciate the caregivers who gave consent for their children to participate in the study.

\section{Conflicts of Interest}

The authors declare no conflicts of interest regarding the publication of this paper.

\section{References}

[1] Black, R.E., Cousens, S., Johnson, H.L., Lawn, J.E., et al. (2010) Global, Regional, and National Causes of Child Mortality in 2008: A Systematic Analysis. The Lancet, 375, 1969-1987. https://doi.org/10.1016/S0140-6736(10)60549-1

[2] Walker, C.L., Rudan, I., Liu, L., Nair, H., et al. (2013) Global Burden of Childhood Pneumonia and Diarrhoea. The Lancet, 38, 1405-1416. https://doi.org/10.1016/S0140-6736(13)60222-6

[3] Akihara, S., Phan, T.G., Nguyen, T.A., et al. (2005) Existence of Multiple Outbreaks of Viral Gastroenteritis among Infants in a Day Care Center in Japan. Achieves of Virology, 150, 2061-2075. https://doi.org/10.1007/s00705-005-0540-y

[4] Filho, E.P., da Costa Faria, N.R., Fialho, A.M, de Assis, R.S., et al. (2007) Adenoviruses Associated with Acute Gastroenteritis in Hospitalized and Community Children up to 5 Years Old in Rio de Janeiro and Salvador, Brazil. Journal of Medical Microbiology, 56, 313-319. https://doi.org/10.1099/jmm.0.46685-0

[5] Akan, H., Izbirak, G., Gurol, Y., Sarikaya, S., et al. (2009) Rotavirus and Adenovirus Frequency among Patients with Acute Gastroenteritis and Relationship to Clinical Parameters: A Retrospective Study in Turkey. Asia Pacifica Family Medicine, 8, 8. https://doi.org/10.1186/1447-056X-8-8

[6] Tagbo, B.N., Mwenda, J.M., Armah, G., Obidike, E.O., Okafor, U.H., Oguonu, T., et al. (2014) Epidemiology of Rotavirus Diarrhea among Children Younger than 5 Years in Enugu, South East Nigeria. The Pediatric Infectious Disease Journal, 33, S19-S22. https://doi.org/10.1097/INF.0000000000000047 
[7] Tate, J.E., Burton, A.H., Boschi-Pinto, C., Parashar, U.D., et al. (2016) Global, Regional, and National Estimates of Rotavirus Mortality in Children < 5 Years of Age, 2000-2013. Clinical Infectious Diseases, 62, S96-S105. https://doi.org/10.1093/cid/civ1013

[8] World Health Organization (2016) Estimated Rotavirus Death for Children under 5 Years of Age 2013. World Health Organization Bulletin 2016.

https://www.who.int/immunization/monitoring_surveillance/burden/estimates/rota virus/en/

[9] Moyo, S.J., Blomberg, B., Hanevik, K., Kommedal, O., et al. (2014) Genetic Diversity of Circulating Rotavirus Strains in Tanzania Prior to the Introducing Vaccination. PLoS ONE, 9, e97562. https://doi.org/10.1371/journal.pone.0097562

[10] Jones, M.S., Harrach, B., Ganac, R.D., Gozum, M.M, et al. (2007) New Adenovirus Species Found in a Patient Presenting with Gastroenteritis. Journal of Virology, 81, 5978-5984. https://doi.org/10.1128/JVI.02650-06

[11] Eckardt, A.J. and Baumgart, D.C. (2011) Viral Gastroenteritis in Adults. Recent Patents on Anti-Infective Drug Discovery, 6, 54-63. https://doi.org/10.2174/157489111794407877

[12] Enugu Weather. https://www.igboguide.org $>$ HT-chapter2.htm

[13] Omoigberale, A.I., Ojukwu, J.O. and Abiodun, P.O. (1996) Asymptomatic Rotavirus Infection within Benin City Urban Community, Nigeria. East African Medical Journal, 73, 688-690. http://europepmc.org/abstract/med/8997852

[14] Page, A.L., Jusot, V., Mamaly, A.A., Ademou, L., et al. (2014) Rotavirus Surveillance in Urban and Rural Areas of Niger. Emerging Infectious Diseases, 20, 573-580. https://doi.org/10.3201/eid2004.131328

[15] Bonkoungou, I., Damanka, S., Sanou, I., Tiendrebeogo, F., et al. (2011) Genotype Diversity of Group A Rotavirus Strains in Children with Acute Diarrhea in Urban Burkina Faso, 2008-2010. Journal of Medical Virology, 83, 1485-1490. https://doi.org/10.1002/jmv.22137

[16] Sherchand, J.B., Schluter, W.W., Sherchen, J.B., Tandukar, S., et al. (2012) Prevalence of Group A Human Rotavirus among Children with Diarrhea in Nepal, 2009-2011. WHO Southeast Asia Journal of Public Health, 1, 432-440. https://doi.org/10.4103/2224-3151.207045

[17] Tagbo, B.N., Mwenda, J.M., Eke, C.B., Edulu, B.O., et al. (2018) Rotavirus Diarrhoea Hospitalizations among Children under 5 Years of Age in Nigeria, 2011-2016. Vaccine, 36, 7759-7764. https://doi.org/10.1016/j.vaccine.2018.03.084

[18] Uzoma, E.B., Chukwubikem, C., Omoyibo, E. and Tagbo, O. (2016) Rotavirus Genotypes and the Clinical Severity of Diarrhoea among Under-Five Years of Age.

Nigeria Postgraduate Medical Journal, 23, 1-5.

https://doi.org/10.4103/1117-1936.180108

[19] Aminu, M., Ahmad, A.A., Umoh, J.U., Beer, M.C., et al. (2007) Adenovirus Infection in Children with Diarrhoea Disease in Northwestern Nigeria. Annals of African Medicine, 6, 168-173. http://www.annalsafrmed.org/text.asp?2007/6/4/168/55702 https://doi.org/10.4103/1596-3519.55702

[20] Mukhtar, G.L., Aminu, M. and Yakubu, S.E. (2015) Prevalence of Adenovirus Infection in Children with Diarrhoea in Katsina State, Northwestern Nigeria. Katsina Journal of Natural and Applied Sciences, 4, 131-137. https://www.umyu.edu.ng/images/kajoNAS/16._Mukhtar_G_L_131_137.pdf

[21] Babalola, M., Odaibo, G., Olaleye, D. and Alonge, A.O. (2015) Enteric Adenovirus and Norovirus Gastroenteritis among Under-5 Years Children in Owo, Ondo State, 
Nigeria. British Journal of Medicine and Medical Research, 9, 1-9.

https://doi.org/10.9734/BJMMR/2015/14082

https://pdfs.semanticscholar.org/0bc7/08db87650657076e49cca734f3a06d0dc1ab.pd $\underline{\mathrm{f}}$

[22] Kajbaf, T.Z., Shamsizadeh, A., Kalvandi, G. and Macvandi, M. (2013) Relative Frequency of Rotavirus and Adenovirus among Children Aged 1-60 Months Hospitalized with Acute Diarrhoea in South Western, Iran. Jundishapur Journal of Microbiology, 6, 47-50. https://doi.org/10.5812/jjm.4072

[23] Al-Sayidi, R.H., Fadhil, H.Y. and Al-Hamdani, F.G. (2014) Rapid Diagnosis of Rota-Adenoviruses for Acute Gastroenteritis in Hospitalized Children under 4 Years Old, Baghdad. International Journal of Current Microbiology and Applied Sciences, 3, 453-458.

https://www.ijcmas.com/vol-3-2/Razaq\%20Hadi\%20Eissa\%20Al-Sayidi,\%20et\%20al $\underline{\text { pdf }}$

[24] Mayindou, G., Ngokana, B., Sidibe, A., Moundele, V., et al. (2015) Molecular Epidemiology and Surveillance of Circulating Rotavirus and Adenovirus in Congolese Children with Gastroenteritis. Journal of Medical Virology, 88, 596-605. https://doi.org/10.1002/jmv.24382

[25] Imade, P.E. and Eghafona, N.D. (2015) Viral Agents of Diarrhea in Young Children in Two Primary Health Centers in Edo State, Nigeria. International Journal of Microbiology, 2015, Article ID: 685821. https://doi.org/10.1155/2015/685821

[26] Motamedifer, M., Amini, E. and Shirazi, P.T. (2013) Frequency of Rotavirus and Adenovirus Gastroenteritis among Children in Shiraz, Iran. Iranian Red Crescent Medical Journal, 15, 729-733. https://doi.org/10.5812/ircmj.4415

[27] Jaff, D.O., Aziz, T.A.G. and Smith, N.R. (2016) The Incidence of Rotavirus and Adenovirus Infections among Children with Diarrhea in Sulaimani Province, Iraq. Journal of Biosciences and Medicines, 4, 124-131. https://doi.org/10.4236/jbm.2016.41015

[28] Steele, A.D., Madhic, S.A., Cunliffed, N.A., Vesikarie, T., et al. (2016) Incidence of Rotavirus Gastroenteritis by Age in African, Asian and European Children: Relevance for Timing of Rotavirus Vaccination. Human Vaccines and Immunotherapeutics, 12, 2406-2412. https://doi.org/10.1080/21645515.2016.1179412

[29] World Health Organization (2013) Rotavirus Vaccines. WHO Position Paper. Vaccines, 31, 6170-6171. https://doi.org/10.1016/j.vaccine.2013.05.037

[30] Ribeiro, J., Ferreira, D., Arrabal, D.A., Almeida, S., et al. (2015) Prevalence of Adenovirus and Rotavirus Infection in Immunocompromised Patients with Acute Gastroenteritis in Portugal. World Journal of Virology, 4, 372-376. https://doi.org/10.5501/wjv.v4.i4.372

[31] Junaid, S.A., Umeh, C., Olabode, A. and Banda, J. (2011) Incidence of Rotavirus Infection in Children with Gastroenteritis Attending Jos University Teaching Hospital Nigeria. Virology Journal, 8, 233-241. https://doi.org/10.1186/1743-422X-8-233

[32] Rodrigues, A., de Carvalho, M., Monteiro, S., Mikkelson, S.C., et al. (2007) Hospital Surveillance of Rotavirus Infection and Nosocomial Transmission of Rotavirus Disease among Children in Guinea-Bissau. The Pediatrtic Infectious Disease Journal, 26, 233-237. https://www.ncbi.nlm.nih.gov/pubmed/17484220 https://doi.org/10.1097/01.inf.0000254389.65667.8b

[33] Fau, C., Billaud, G., Pinchinat, S., Lina, B., et al. (2008) Epidemiology and Burden of Rotavirus Diarrhea in Day Care Centers in Lyon, France: 2004-2005. Archives of Pediatric Journal, 15, 1183-1192. https://doi.org/10.1016/j.arcped.2008.02.016 
[34] Aminu, M., Page, N.A., Ahmad, A.A., Umoh, J., Drawer, G. and Steele, D. (2010) Diversity of Rotavirus VP7 and VP4 Genotypes in North Western Nigeria. Journal of Infectious Diseases, 202, S198-S204. https://doi.org/10.1086/653570

[35] Tsolenganu, E., Sleheri, M., Dagnra, A., Djadou, E., et al. (2014) Surveillance for Rotavirus Gastroenteritis in Children Less than 5 Years of Age in Togo. The Pediatric Infectious Disease Journal, 33, S14-S18. https://doi.org/10.1097/INF.0000000000000046

[36] Basu, G., Rossouw, J., Sebunya, B.A., De Beer, J.B., et al. (2003) Prevalence of Rotavirus, Adenovirus and Astrovirus Infection in Young Children with Gastroenteritis in Gaborone, Botswana. East African Medical Journal, 80, 653-655.

http://journals.uonbi.ac.ke/files/journals/1/articles/654/submission/review/654-243 3-1-RV.pdf https://doi.org/10.4314/eamj.v80i12.8783

[37] Biswajyoti, B., Aniruddha, J., Chandrakanta B., Das, M., et al. (2016) Prevalence of Enteric Adenovirus among Non-Rotavirus Diarrhoea in Assam, Northeast India. International Journal of Medical Research Professionals, 2, 124-130.

https://doi.org/10.21276/ijmrp.2016.2.5.025 http://ijmrp.com/ViewArchive.aspx?.vol=2\&issue $=5$ \&year $=2016$

[38] WHO (2019) Summary of Key Characteristics of Currently WHO-Pre-Qualified Rotavirus Vaccines.

https://www.who.int/immunization/diseases/rotavirus/WHO_Summary_xtics_PQ' d_rota_vaccines.PDF?ua $=1$ 